\title{
Root Distribution of Brassica napus and Vicia faba within the Sheath of Root or Earthworm Biopore
}

\author{
Lisa Petzoldt *(D) and Timo Kautz
}

check for updates

Citation: Petzoldt, L.; Kautz, T. Root Distribution of Brassica napus and Vicia faba within the Sheath of Root or Earthworm Biopore. Agriculture 2021, 11, 61. https://doi.org/10.3390/ agriculture11010061

Received: 29 November 2020 Accepted: 8 January 2021 Published: 13 January 2021

Publisher's Note: MDPI stays neutral with regard to jurisdictional clai$\mathrm{ms}$ in published maps and institutional affiliations.

Copyright: () 2021 by the authors. Licensee MDPI, Basel, Switzerland. This article is an open access article distributed under the terms and conditions of the Creative Commons Attribution (CC BY) license (https:// creativecommons.org/licenses/by/ $4.0 /)$.
Department of Crop Science, Albrecht Daniel Thaer-Institute of Agricultural and Horticultural Sciences, Humboldt-University of Berlin, Albrecht-Thaer-Weg 5, 14195 Berlin, Germany; timo.kautz@agrar.hu-berlin.de * Correspondence: lisa.petzoldt@hu-berlin.de

\begin{abstract}
Root growth through biopores is facilitated by low mechanical impedance and nutrient enrichment due to the deposition of organic material at the biopore sheath. Plant roots and earthworms impact biopore sheath properties differently. However, the literature lacks a quantitative study of the root distribution within the sheath of pores, which were originated by taproots or earthworms. According to previous literature on pore connectivity, it can be hypothesized that precrops encourage root growth into the biopore sheath in comparison to an earthworm characterized sheath. A pot experiment was performed to compare the root distribution of spring oilseed rape (Brassica napus L.) and faba bean (Vicia faba L.) within the biopore sheath of two different biopore types. The biopore sheath was characterized by taprooted chicory (Cichorium intybus L.) or anecic earthworm (Lumbricus terrestris L.). Roots were sampled at the biopore lumen and at lateral distances of 0-2, 2-4, 4-8 (sheath) and 20-36 mm (bulk soil) from the biopore wall surface. In both pore types $>50 \%$ of the root length $(\mathrm{cm})$ and $>70 \%$ fine roots of oilseed rape were found in a comparatively small soil area (Lumen $+2 \mathrm{~mm}$ ). On the contrary, faba bean grew primarily through the bulk soil with $>75 \%$ root length and rarely into the biopore sheath in both pore types. In both species there was a lateral decrease of the total nitrogen $\left(\mathrm{N}_{\mathrm{t}}\right)$-content from biopore wall (Mean \pm SE: $0.061 \% \pm 0.002 \%$ ) to bulk soil $(0.053 \% \pm 0.002 \%)$, but no significant difference between the pore types. The results of the current study illustrate that the root growth of spring oilseed rape and faba bean was not encouraged by the precrop in comparison to the earthworm characterized sheath.
\end{abstract}

Keywords: allorhizous root system; biopore sheath; biopore type; root diameter; root-length-density

\section{Introduction}

Biopores are predominantly formed by earthworms and plant roots. Large-sized biopores (diameter $>5 \mathrm{~mm}$ ) are cylindrical shaped continuous macropores found in untilled soil layers. In the field, roots and earthworms may interact when forming those pathways, or they may occupy them alternately, but both influence the properties [1,2]. In studies on large-sized biopores the effect on root growth within the sheath has not been considered. However, based on the characteristics of the sheath, root-soil contact can be encouraged or diminished. This can be important for nutrient acquisition.

There is already documentation in the literature about the biological, chemical and physical properties of the soil around biopores (sheath), which is different compared to the macropore uninfluenced soil (bulk soil) (e.g., [3]). However, the spatial extent of the biopore sheath varies. For instance, the pore surrounding soil area defines the sheath, which contains $80 \%$ of macropore related roots [4]. According to its physical properties, the sheath was found as a concentric area around the macropore with a higher bulk density up to $2.2 \mathrm{~cm}$ in radius compared to bulk soil [5]. Previous studies on biochemical properties in biopores found a higher content of macronutrients, accumulation of organic material, and a higher microbial and enzyme activity at the biopore wall and sheath [6-8]. The elevated nutrient enrichment occurs in regions from 0 to $8 \mathrm{~mm}$ in the sheath [3,7,9-12]. Furthermore, 
biopores have a higher exchange of gas and air [13], and less mechanical impedance for roots due to the air-filled lumen. These advantageous properties can allow for plant roots to bypass compacted soil layers [14]. Biopores are considered as preferential pathways for roots [14] when reaching water in deeper soil layers during dry spells [15], as well as reaching deeper soil layers faster [16]. It may help plants to find nutrients, when the topsoil is nutrient depleted $[17,18]$. This is important, especially in organic farming systems, where nearly closed nutrient-cycles are sought.

Root-soil contact is crucial for nutrient acquisition from the solid soil phase. Thus, in biopores where the pore diameter can be several times larger than the root diameter, rootsoil contact will be established at the biopore wall and by roots entering the sheath. The ease of entering biopore sheath is influenced by rewetting-drying cycles regarding anchorage at pore wall [19], bulk density [20], and presumably by lateral pores, which may have been formed by precrops $[13,21,22]$. Precrops, such as lucerne (Medicago sativa L.) or chicory increased biopore density [23,24], and root-length-density (RLD) [25] or shifted the root diameter [26] of the subsequent crop. Furthermore, roots were observed following precrop pathways [21], entering the biopore wall [27] and were located within the sheath [28]. Due to sheath growth, it can be assumed that roots leave lateral pores after their decay and therefore promote root growth along the biopore sheath. Earthworms instead might hinder root growth into the sheath due to a reduced porosity [29] and disconnected lateral pores [30] in the biopores sheath after earthworm activity. Hence, a homogenous arrangement of soil particles [5] in combination with mucus and linings of earthworms [9] could impede root growth, because of axial resistance [31]. At the same time, earthworm casts lead to an enrichment of plant-available nutrients particularly at the initial millimeters of the sheath by adding their linings at the biopore wall $[8,32]$. That on the other hand can promote root growth, especially the growth of fine roots [33]. It can therefore be suggested that roots growing through worm type pores are located at biopore walls rather than at the sheath of $0-8 \mathrm{~mm}$ distance from macropore.

Root growth through biopores appears to be of varying importance for different root systems [16] or plant species [34] and is influenced by soil compaction and moisture $[14,15,35,36]$. Perkons [16] found a higher share of allorhizous roots in biopores than in homorhizous species. That aligns partly with the results of Athmann et al. [34], who found that oilseed rape was most attracted by biopores, followed by wheat, barley, and lastly faba bean. Faba bean as well as oilseed rape are reported as reacting sensitively to soil compaction $[37,38]$, which in turn would lead to an attraction to pathways without mechanical impedance. However, in terms of nutrient supply, Li et al. [39] found less root plasticity of faba bean than maize and wheat. Thus, it can be assumed that oilseed rape and faba bean react differently to the biopore sheath.

This study focuses on root and worm type biopore sheaths and their effects on the root distribution of two allorhizous crops by investigating the following hypotheses:

(i) The RLD and the share of fine roots (root diameter $\leq 0.2 \mathrm{~mm}$ ) is higher in the biopore sheath $(0-8 \mathrm{~mm})$ of root type than of worm type biopore,

(ii) there is a higher RLD of oilseed rape in the biopore sheath than of faba bean, and

(iii) the decrease of the $\mathrm{N}_{\mathrm{t}}$ - and $\mathrm{C}_{\mathrm{t}}$-content is sharper in the worm type than in the root type biopore sheath from biopore surface until $8 \mathrm{~mm}$ distance from macropore.

\section{Materials and Methods}

\subsection{Experimental Setup}

A pot experiment was performed to investigate the root growth of spring oilseed rape (Brassica napus L.) and faba bean (Vicia faba L.) in the biopore sheath of two different biopore types. The soil columns had a height of $60 \mathrm{~cm}$ and a diameter of $10 \mathrm{~cm}$. The soil was divided into a topsoil layer of $10 \mathrm{~cm}$ and a subsoil layer of $50 \mathrm{~cm}$. The top- and subsoil of a Haplic Luvisol [40] was collected from a field site in Klein-Altendorf near Bonn, Germany $\left(50^{\circ} 37^{\prime} 8.5^{\prime \prime} \mathrm{N}, 6^{\circ} 59^{\prime} 25.4^{\prime \prime} \mathrm{E}\right)$. The topsoil was collected from 5 to $30 \mathrm{~cm}$ depth and the subsoil from 45 to $105 \mathrm{~cm}$ depth. The subsoil was homogenized, sieved $\leq 2 \mathrm{~mm}$ and 
filled into plastic pipes. The soil was compacted with a hydraulic device to a bulk density of $1.5 \mathrm{~g} \mathrm{~cm}^{-3}$. At the beginning of the experiment the soil moisture was adjusted to a water content of $18 \%$. One artificial vertical pore with a diameter of $6 \mathrm{~mm}$ was formed in the center of each column by using an iron rod.

In the first part of the experiment (Table 1), the columns were either cultivated with one individual adult anecic earthworm (Lumbricus terrestris L.) or with one seedling of chicory (Cichorium intybus L. 'Puna'). Chicory was chosen, because of its ability to form large-sized biopores, which resulted in higher RLD of the subsequent crops in subsoil [25]. The chicory was cultivated for twelve weeks in a greenhouse. The cultivation followed natural day and night rhythm, with irrigation adapted to plant growth, a daytime temperature of about $20^{\circ} \mathrm{C}$ and a nighttime temperature of $16^{\circ} \mathrm{C}$. The earthworms were incubated for eight weeks. During the earthworm incubation the columns were kept at $12{ }^{\circ} \mathrm{C}\left( \pm 2{ }^{\circ} \mathrm{C}\right)$. The earthworms were fed with dried chicory ( $0.7 \mathrm{~g}$ per week) and the soil was irrigated with $25 \mathrm{~mL}$ distilled water every second week. After eight weeks the earthworms were removed using a heated water bath. The water bath was kept at $40^{\circ} \mathrm{C}$, until the soil column was warmed up to $20^{\circ} \mathrm{C}$. Then the earthworms moved to the soil surface. After twelve weeks the chicory growth was stopped by cutting the shoot and treating the root with the pesticide 'Arrat and dash' (BASF, Ludwigshafen, Germany). The total decay time was thirteen months.

Table 1. Timeline with the different stages of the experiment.

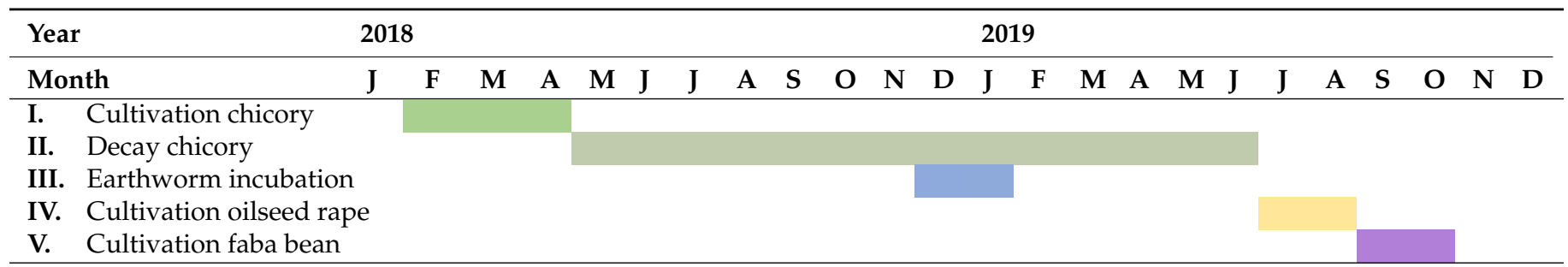

In the second part of the experiment, two crops were cultivated separately. For the main crop cultivation the topsoil layer was prepared on top of the subsoil-column. The topsoil was filled in a cap and pressed to a bulk density of $1.3 \mathrm{~g} \mathrm{~cm}^{-3}$. Twelve columns in total per crop, i.e., six columns per treatment (earthworm versus root biopore) were cultivated with spring oilseed rape 'Ability' for six weeks and faba bean 'Fanfare' for seven weeks. These different durations were dependent on species specific root elongation. The main crops were chosen, because both species reacted sensitive to soil compaction [37,38], but dispose about different $\mathrm{N}$-foraging strategies. The cultivation was proceeded under a natural day and night rhythm and temperature, as well as regular irrigation adapted to plant growth. At time of sampling spring oilseed rape was in DC 32-55 and faba bean in DC 39-59 (BBCH-scale [41]).

At the end of the experiment the shoot biomass was analyzed for nutrient-state of $\mathrm{N}$, $\mathrm{P}, \mathrm{K}$. For the measurements at the biopores, the subsoil section of a column was divided into $4 \times 10 \mathrm{~cm}$ high sections. The $5 \mathrm{~cm}$-section between the top- and subsoil layer and the $5 \mathrm{~cm}$-section at the bottom of the column were discarded. The residual $10 \mathrm{~cm}$-sections were vertically cut in half. Then the roots were removed from the biopore lumen and the sheath was sampled in lateral distances of: $0-2,2-4,4-8 \mathrm{~mm}$. The bulk soil was sampled in 20-36 mm distance from biopore wall (Figure 1). A newly designed scraping device was used for sampling (described in [28]). The diameter of the biopore was measured at each section to calculate the biopore volume and the volume of the lateral distances of the sheath. With the volume of the sampled area, the RLD can be achieved for the lumen, each lateral distance and the bulk soil. The samples were prepared, scanned and measured as described in detail in Petzoldt et al. [28]. 


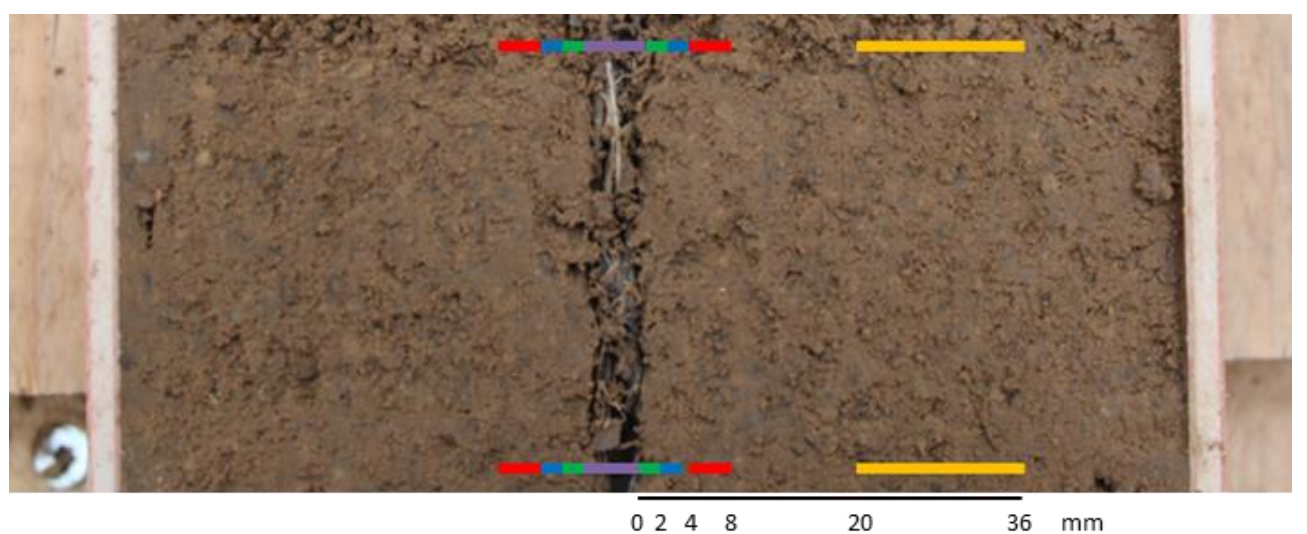

Figure 1. Sampling of the biopore lumen (purple), biopore sheath (green, blue, red) and bulk soil (yellow). Lateral distances in $[\mathrm{mm}]$ from the pore wall surface.

\subsection{Statistical Data Analysis}

According to Petzoldt et al. [28] the data analyses for spring oilseed rape and faba bean were done separately using the packages SAS/BASE and SAS/STAT 14.3 of the software SAS 9.4 TS1M5 (2016) (SAS Institute Inc., Cary, NC, USA). With the procedure MIXED of SAS/STAT [42] a completely randomized block design with a Linear Mixed Model with fixed effects for pore type, lateral distance, depth interval and interaction of pore type lateral*depth, and a random effect of pore was fitted using Restricted Maximum Likelihood (REML, [43]). Based on the variance estimates of the Linear Mixed Model, multiple mean comparison tests were applied for differences between the levels of the lateral distances within each level of depth interval between or within the respective biopore type. The adjustment for the multiple comparisons was done by the procedure of Tukey's Honestly Significant Difference $(\alpha=0.05)$ based on Piepho [44]. Further details are described in Petzoldt et al. [28]. The adjustment was done by Dunnett-test [45] in order to compare the total nitrogen $\left(\mathrm{N}_{\mathrm{t}}\right)$ - and total carbon $\left(\mathrm{C}_{\mathrm{t}}\right)$-content of the lateral distances with the content of the bulk soil (control).

\section{Results}

\subsection{Root Distribution}

There was a lateral decrease in the RLD of spring oilseed rape from lumen towards bulk soil (Figure 2). The RLD was significantly higher in the lumen compared to the RLD within the sheath and the bulk soil. Regarding the biopore sheath the RLD in 0-2 mm lateral distance was significantly higher than the RLD in the layer of 2-4 and 4-8 mm lateral distance. There was no difference between the biopore types. In every single column cultivated with oilseed rape the roots were growing through the pore lumen, which was not observed for faba bean. The RLD of faba bean was higher in the lumen of both pore types, whereby in worm type the difference between the lumen and sheath (0-8 $\mathrm{mm}$ distance) was significant. There was no difference between the RLD in the sheath and bulk soil of both types. Overall, the RLD of faba bean was less than the RLD of oilseed rape and the variance of the RLD was higher for faba bean. 


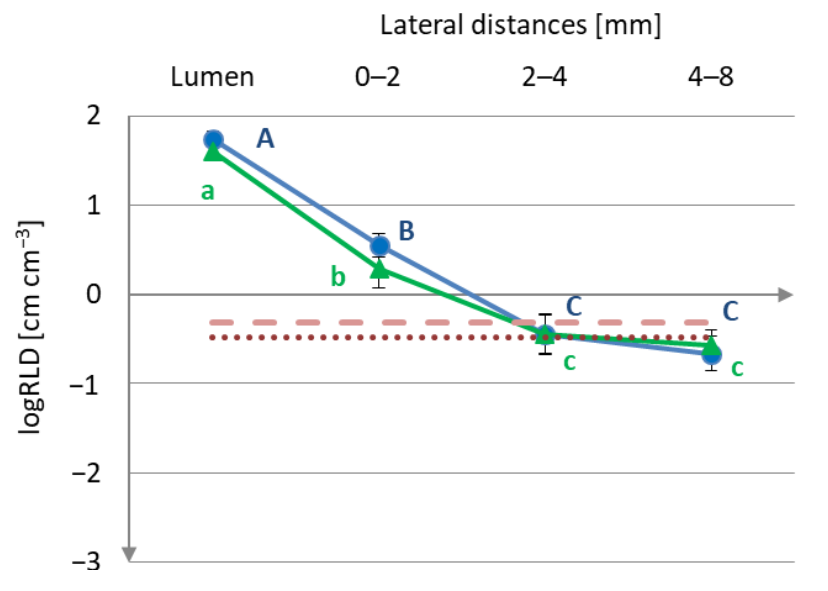

Spring oilseed rape

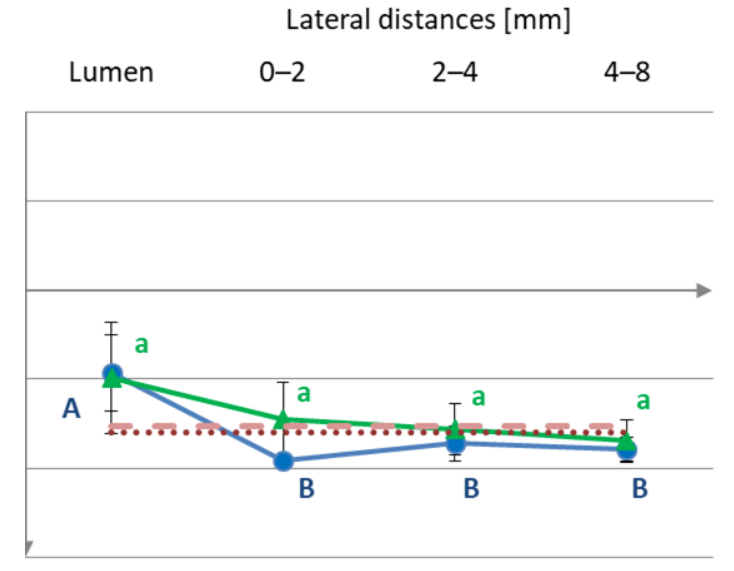

Faba bean

Figure 2. Log10-transformed RLD $\left[\mathrm{cm} \mathrm{cm}^{-3}\right]$ of spring oilseed rape and faba bean in different biopore types (worm type = blue; root type $=$ green). Mean and SE of lateral distances. Means not sharing a common letter indicate significant differences between lateral distances (Tukey-HSD, $\alpha=0.05$ ); Uppercase letters show differences for worm type and lowercase letters for root type. Red lines show the mean of the bulk soil sample for the root $\left(^{-}\right)$or worm type $(\cdots \cdots \cdot)$ treatment.

In the lumen and sheath of worm pores $70-84 \%$, and of root pores $75-89 \%$ of oilseed rape roots were classified as fine roots (Table 2); followed by diameter class small (worm pore: $15-34 \%$, root pore: $10-34 \%$ ), medium (worm pore: $1-4 \%$, root pore: $0.4-3.5 \%$ ) and coarse (worm pore: $0-2 \%$, root pore: $0-1.5 \%$ ). Coarse roots were scarcely found in the sheath and bulk soil in both biopore types. Small roots were found with a higher share of small roots in the sheath of 2-8 $\mathrm{mm}$ distance from macropore and bulk soil. In diameter class fine, there were differences between lumen, sheath, and bulk soil, with a decreasing share from biopore wall to bulk soil. There was no difference in the amount of fine roots between root and worm type. The classification of faba bean roots into diameter classes was not appropriate due to less root data within the sheath for calculating the mean and SE.

Table 2. Proportion of root length [\%] of spring oilseed rape categorized in diameter classes [mm]. Mean and SE of lateral distances. Means not sharing a common letter indicate significant differences (Tukey-HSD, $\alpha=0.05$ ); ns = not significant.

\begin{tabular}{|c|c|c|c|c|c|c|c|c|c|c|c|c|c|c|c|c|c|}
\hline Pore Type & $\begin{array}{l}\text { Lateral } \\
\text { Distance } \\
{[\mathrm{mm}]}\end{array}$ & \multicolumn{3}{|c|}{$\begin{array}{l}\text { Fine } \\
0-0.2 \mathrm{~mm} \\
{[\%]} \\
\text { Mean }\end{array}$} & SE & \multicolumn{3}{|c|}{$\begin{array}{l}\text { Small } \\
0.2-0.4 \mathrm{~mm} \\
{[\%]} \\
\text { Mean }\end{array}$} & SE & \multicolumn{3}{|c|}{$\begin{array}{l}\text { Medium } \\
0.4-0.6 \mathrm{~mm} \\
{[\%]} \\
\text { Mean }\end{array}$} & \multirow{2}{*}{$\begin{array}{l}\text { SE } \\
1.02\end{array}$} & \multicolumn{2}{|c|}{$\begin{array}{l}\text { Coarse } \\
>0.6 \mathrm{~mm} \\
{[\%]} \\
\text { Mean }\end{array}$} & & SE \\
\hline \multirow{5}{*}{ Worm } & Lumen & 80.0 & $a b$ & \pm & 2.71 & 15.1 & $b$ & \pm & 2.12 & 2.75 & ns & \pm & & 2.18 & a & \pm & 0.97 \\
\hline & $0-2$ & 83.8 & a & \pm & 4.18 & 15.1 & $b$ & \pm & 3.42 & 1.04 & ns & \pm & 0.58 & 0.10 & $\mathrm{~b}$ & \pm & 0.08 \\
\hline & $2-4$ & 73.5 & $\mathrm{bc}$ & \pm & 8.11 & 25.0 & $a b$ & \pm & 7.31 & 1.05 & ns & \pm & 0.86 & 0.50 & $\mathrm{~b}$ & \pm & 0.50 \\
\hline & $4-8$ & 70.2 & bc & \pm & 7.24 & 26.6 & a & \pm & 5.90 & 3.18 & ns & \pm & 1.91 & 0.07 & $\mathrm{~b}$ & \pm & 0.07 \\
\hline & bulk & 62.0 & c & \pm & 5.65 & 33.6 & a & \pm & 5.04 & 4.18 & ns & \pm & 1.30 & 0.26 & $\mathrm{~b}$ & \pm & 0.17 \\
\hline \multirow{5}{*}{ Root } & Lumen & 79.6 & $\mathrm{~b}$ & \pm & 3.63 & 16.7 & $b$ & \pm & 2.04 & 2.25 & ns & \pm & 1.00 & 1.44 & ns & \pm & 1.11 \\
\hline & $0-2$ & 89.4 & $\mathrm{a}$ & \pm & 4.88 & 10.1 & $\mathrm{~b}$ & \pm & 3.50 & 0.44 & ns & \pm & 0.38 & 0.01 & ns & \pm & 0.01 \\
\hline & $2-4$ & 74.9 & $a b c$ & \pm & 6.64 & 23.4 & $a b$ & \pm & 8.36 & 1.70 & ns & \pm & 1.49 & 0.01 & ns & \pm & 0.01 \\
\hline & $4-8$ & 79.6 & $a b$ & \pm & 5.10 & 19.4 & $a b$ & \pm & 5.46 & 1.00 & ns & \pm & 0.75 & 0.03 & ns & \pm & 0.03 \\
\hline & bulk & 62.6 & c & \pm & 7.87 & 33.9 & a & \pm & 8.02 & 3.48 & ns & \pm & 2.48 & 0.05 & ns & \pm & 0.05 \\
\hline
\end{tabular}

The estimation of the proportion of the root length per subsoil area resulted in a higher proportion of roots of oilseed rape in biopore lumen and sheath with $>50 \%$ in comparison to bulk soil in both pore types (Table 3). In faba bean most roots were located with $>75 \%$ in the bulk soil. The biopore lumen with a diameter of $8 \mathrm{~mm}$ amounted $0.63 \%$ and the biopore sheath $5.02 \%$ of the subsoil area of the vessels. At time of sampling $3.49 \%$ of the root length 
of oilseed rape was found in worm type sheath and $5.02 \%$ in root type sheath. In faba bean $0.92 \%$ root length was found in worm type sheath and $3.12 \%$ in root type sheath.

Table 3. Estimation of the soil area and the root distribution of spring oilseed rape and faba bean in worm or root type treatment. The mean root length (RL) in the biopore lumen, biopore sheath (0-2, 2-4, 4-8 mm) and bulk soil (20-36 mm) was estimated in $0.003 \mathrm{~m}^{3}$ subsoil per column; Average biopore diameter of the sampled biopores under study: $8 \mathrm{~mm}$, and sampling depth: $15-55 \mathrm{~cm}$.

\begin{tabular}{|c|c|c|c|c|c|c|c|c|c|c|c|}
\hline & & \multicolumn{2}{|c|}{ Lumen } & \multicolumn{2}{|c|}{ 0-2 mm } & \multicolumn{2}{|c|}{$2-4 \mathrm{~mm}$} & \multicolumn{2}{|c|}{$4-8 \mathrm{~mm}$} & \multicolumn{2}{|c|}{ Bulk Soil } \\
\hline & & Worm & Root & Worm & Root & Worm & Root & Worm & Root & Worm & Root \\
\hline \multicolumn{2}{|c|}{ Share of subsoil volume [\%] } & 0.63 & & 0.78 & & 1.10 & & 3.14 & & 94.35 & \\
\hline \multirow{2}{*}{ Spring oilseed rape } & Total RL [cm] & 1148.66 & 627.88 & 52.42 & 35.42 & 10.06 & 10.25 & 14.85 & 18.78 & 990.12 & 593.02 \\
\hline & Share RL [\%] ${ }^{*}$ & 51.83 & 48.84 & 2.37 & 2.76 & 0.45 & 0.80 & 0.67 & 1.46 & 44.69 & 46.14 \\
\hline \multirow{2}{*}{ Faba bean } & Total RL [cm] & 9.77 & 25.84 & 0.06 & 1.51 & 0.54 & 1.10 & 1.32 & 0.89 & 150.82 & 95.60 \\
\hline & Share RL $[\%]$ * & 6.03 & 20.61 & 0.04 & 1.20 & 0.33 & 0.87 & 0.55 & 1.05 & 93.05 & 76.26 \\
\hline
\end{tabular}

* Share of root length over total root length of worm or root type.

\section{2. $N_{t^{-}}$and $C_{t}$-Content}

For both species there was no difference between the biopore types. For faba bean the $\mathrm{N}_{\mathrm{t}}$ - and $\mathrm{C}_{\mathrm{t}}$-content decreased with increasing lateral distance and soil depth (Figure 3). The $\mathrm{N}_{\mathrm{t}}$-content of the biopore sheath of worm pores showed a significant difference in $15-25 \mathrm{~cm}$ soil depth between 0-2 mm lateral distance and bulk soil. In the sheath of root biopores there were significant differences in a soil depth of $15-25 \mathrm{~cm}$ and $25-35 \mathrm{~cm}$ between $0-2 \mathrm{~mm}$ and bulk soil. The $\mathrm{C}_{\mathrm{t}}$-content decreased significantly in worm and root biopores from 0-2 $\mathrm{mm}$ to bulk soil in $15-25 \mathrm{~cm}$ and $25-35 \mathrm{~cm}$ soil depth.

For spring oilseed rape there was no significant difference of the $\mathrm{N}_{\mathrm{t}}$-content. The $\mathrm{C}_{\mathrm{t}}$-content was different in root type in a soil depth of $15-25 \mathrm{~cm}$ between $0-2 \mathrm{~mm}$ sheath and bulk soil. 


\section{$\mathrm{N}_{\mathrm{t}}[\%]$}
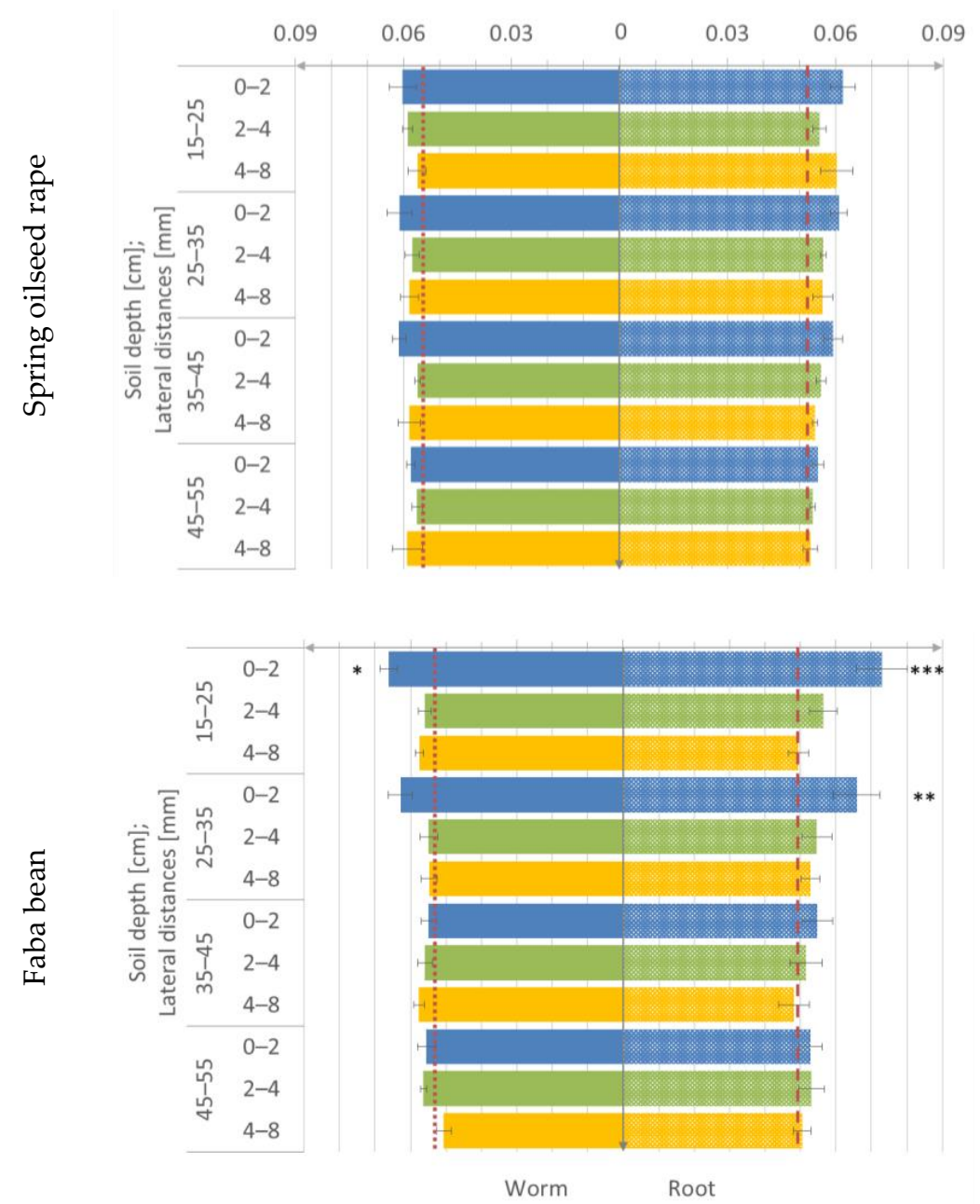

$\mathrm{C}_{\mathrm{t}}[\%]$

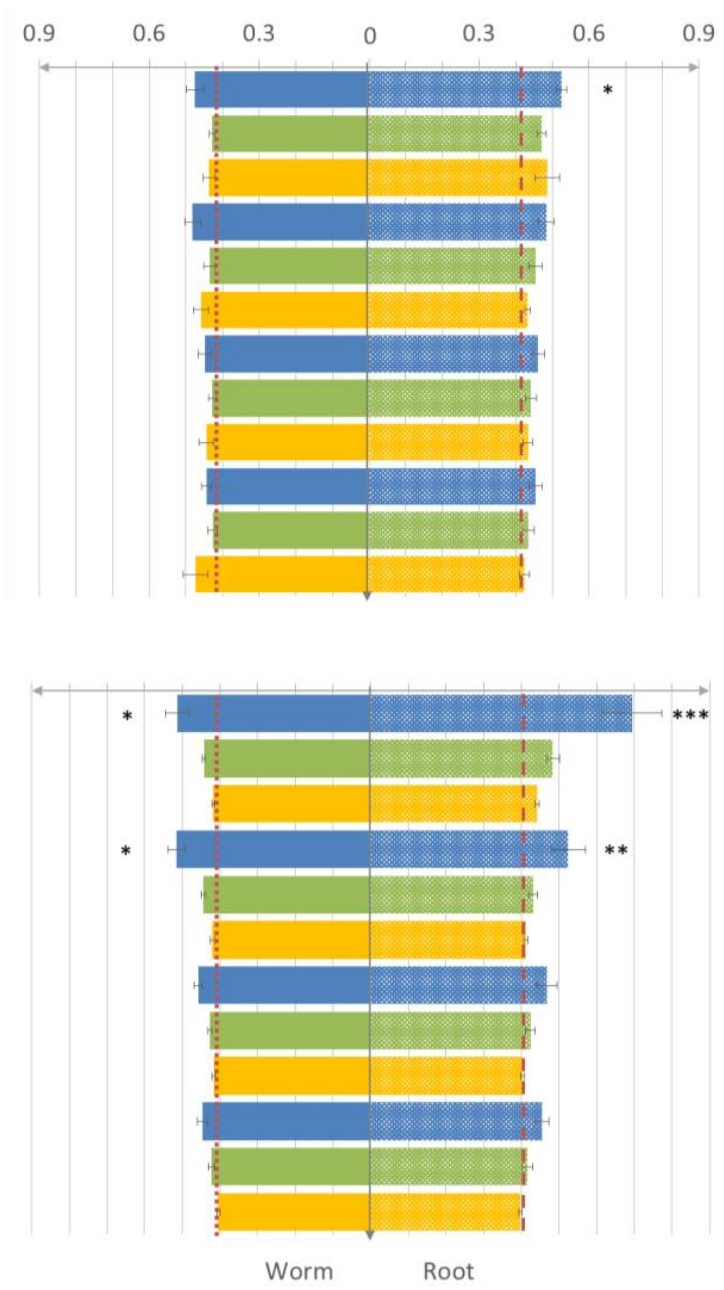

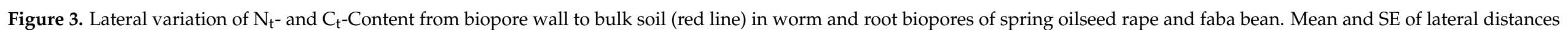

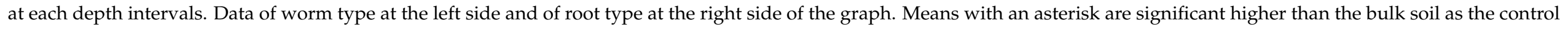
(Dunnett-test, $\alpha=0.05 ; p^{*}<0.05,{ }^{* *}<0.01{ }^{* * *}<0.001$ ); Layers of the biopore sheath in blue $=0-2 \mathrm{~mm}$, green $=2-4 \mathrm{~mm}$ and yellow $=4-8 \mathrm{~mm}$. 


\section{Discussion}

The RLD of oilseed rape sharply decreased laterally from biopore lumen towards 4-8 $\mathrm{mm}$ biopore sheath of both pore types. It can be suggested that this lateral decrease is mainly related to roots, which entered the sheath by passing through the lumen. Conversely to oilseed rape, faba bean was growing with a higher share of roots through the bulk soil and rarely in the biopore lumen and sheath. That aligns with Athmann et al. [34], who reported a preferential root growth of oilseed rape in biopores in comparison to wheat, barley and faba bean. However, the results of this study show that even if preferential root growth of oilseed rape into biopore lumen occurred, a comparatively small proportion of roots proliferated into the sheath of $0-8 \mathrm{~mm}$ lateral distance in worm as well as in root type pore. Within the sheath they remained mainly at the inner layer of the sheath in both biopore types. That can be related to the $\mathrm{N}$-enrichment at the inner layer of the sheath and/or impeding layers of the sheath of 2-8 $\mathrm{mm}$ distance.

Although both species have an allorhizous root system, they appear to proliferate through heterogenic subsoil differently. This is due to their sensitivity towards mechanical impedance and nutrient supply $[37,38]$. The RLD of less than $1 \mathrm{~cm} \mathrm{~cm}^{-3}$ of faba bean in the biopore lumen and their variance in root data showed no preferential root growth in biopores and sheath. When exposed to mechanical stress, faba bean roots usually become much thicker than the roots of monocots or other dicots [46]. The larger diameter increases their penetration ability [47]. That in turn may help to penetrate a possible impeding layer like the sheath, or linings of earthworms at the pore wall, or to grow through the bulk soil. In this study the bulk density of $1.5 \mathrm{~g} \mathrm{~m}^{-3}$ did not hinder faba bean to grow mainly through the bulk soil. Moreover, faba bean roots reacted with less plasticity to nutrient supply [39]. Therefore, faba bean appeared to be less attracted by pathways with a large-sized lumen and an nutrient-enriched inner layer of the biopore sheath than oilseed rape.

Changes towards a higher concentration of nutrients, such as $\mathrm{N}$, can promote the development of fine roots. Fine roots are important for nutrient uptake [48,49]. In this study the root system of oilseed rape mainly consisted of fine roots with a diameter $\leq 0.2 \mathrm{~mm}$. According to McCormack et al. [49] fine roots of a size of $<0.5 \mathrm{~mm}$ belong to the absorptive fine root pool. The fine roots of oilseed rape were predominantly located in the lumen and $0-2 \mathrm{~mm}$ sheath of both biopore types. That points out either the presence of nutrient uptake, root growth without axial impedance [50] or a radial limitation in the sheath and bulk soil $[21,50]$. In the current study, coarse roots, which are mostly growing vertically and are of a higher order, were mainly located in the lumen. Furthermore, a higher share of roots at the intermediate diameter level (in this study: small and medium) were found in the comparatively denser soil areas (2-8 $\mathrm{mm}$ sheath and bulk soil), which could be due to axial impedance. For both types, there were significantly more fine roots in the lumen and the inner layer of the sheath than in the bulk soil. This can be explained as an effect of the N-enrichment.

However, it was originally hypothesized that the precrop leaves lateral pores, and therefore encourages root growth into the biopore sheath, whereas the earthworm disconnects lateral pores as potential pathways into the sheath [30]. This assumption could not be confirmed in this study, because there were no significant differences found in the root distribution within the sheath between the biopore types. Thus, root growth was not encouraged within root type sheath and not reduced in worm type sheath. However, Lucas et al. [51] showed that establishing a well-connected biopore network by plant roots requires several years. The one-term precrop cultivation in this experiment might have been too short for establishing a well-connected pore network from the large-sized macropore towards bulk soil. In further studies, a better understanding of the imprinting effects on root distribution within the sheath could be achieved by measuring physical properties before and after main crop cultivation, such as pore connectivity by computed-tomography.

In both species there were lateral variations in the sheath of the $\mathrm{N}_{\mathrm{t}}$ - and $\mathrm{C}_{\mathrm{t}}$-content, but no difference between worm and root type. Earthworm linings increase N- and Ccontents in the pore wall and sheath $[8,12]$. In this study, residues of chicory roots also 
contributed to increased $\mathrm{N}_{\mathrm{t}}$ - and $\mathrm{C}_{\mathrm{t}}$-contents in the biopore sheath in faba bean, particularly in the inner layer of the sheath in a soil depth of $15-35 \mathrm{~cm}$. The highly significant $\mathrm{N}_{\mathrm{t}}$ - and $\mathrm{C}_{\mathrm{t}}$-contents in root type can be explained by the root debris of the taprooted precrop, which had completely filled the pore in the upper soil layers at the end of the cultivation period. The lateral decrease of both elements from biopore wall surface towards bulk soil was more expressed in faba bean than in oilseed rape. The more expressed lateral decrease in faba bean is consistent with the findings in a previous field study using the same sampling pattern of the biopore sheath in subsoil [28]. There, the $\mathrm{N}_{\mathrm{t}}$ - and $\mathrm{C}_{\mathrm{t}}$-contents were significantly decreasing from pore wall towards 8 or $12 \mathrm{~mm}$ lateral distance from macropore [28]. Thus, for the Brassicaceae an N-rich pore wall can be more advantageous than it is for the Legume. Considering this, oilseed rape was foraging on $\mathrm{N}$ from the inner layer of the sheath, while faba bean was not dependent on this $\mathrm{N}$ source.

\section{Conclusions}

The results of the root distribution and the proportion of fine roots show no differences within the sheath between both pore types. Earthworm imprinting does not limit root access into the biopore sheath, nor does the precrop encourage it. Beyond that, the results indicate that both crop species have different strategies for growing through heterogenic subsoil. The results about faba bean support the view that faba bean is not necessarily using large-sized biopores and thus also not the biopore sheath, which can be related to a different rooting and foraging behavior. Contrary to that, oilseed rape appears to be attracted by the inner layer of the sheath. This can be due to the accessibility through the macropore as a pathway without mechanical impedance, and the $\mathrm{N}$-enrichment of the inner layer of the sheath of both biopore types.

Author Contributions: Conceptualization, T.K.; Data curation and Investigation, L.P.; Supervision, T.K.; Writing—original draft, L.P.; Writing—review \& editing, T.K. All authors have read and agreed to the published version of the manuscript.

Funding: This research was funded by the German Research Foundation (Deutsche Forschungsgemeinschaft-DFG) within the DFG project KA2703/3-1.

Data Availability Statement: The data presented in this study are available on request from the corresponding author (lisa.petzoldt@hu-berlin.de).

Acknowledgments: The authors are grateful to the technical support by Ina Vogel and by the support of the students Ronja Biermann and Daniel Geidel. We acknowledge support by the German Research Foundation (DFG) and the Open Access Publication Fund of Humboldt-Universität zu Berlin.

Conflicts of Interest: The authors declare that they have no conflict of interest.

\section{References}

1. Springett, J.; Gray, R. The Interaction between Plant Roots and Earthworm Burrows in Pasture. Soil Biol. Biochem. 1997, 29, 621-625. [CrossRef]

2. Zangerlé, A.; Pando, A.; Lavelle, P. Do Earthworms and Roots Cooperate to Build Soil Macroaggregates? A Microcosm Experiment. Geoderma 2011, 167-168, 303-309. [CrossRef]

3. Tiunov, A.V.; Bonkowski, M.; Tiunov, J.A.; Scheu, S. Microflora, Protozoa and Nematoda in Lumbricus terrestris Burrow Walls: A Laboratory Experiment. Pedobiology 2001, 45, 46-60. [CrossRef]

4. Stewart, J.; Moran, C.; Wood, J. Macropore Sheath: Quantification of Plant Root and Soil Macropore Association. Plant Soil 1999, 211, 59-67. [CrossRef]

5. Schrader, S.; Rogasik, H.; Onasch, I.; Jégou, D. Assessment of Soil Structural Differentiation around Earthworm Burrows by Means of X-ray Computed Tomography and Scan-Ning Electron Microscopy. Geoderma 2007, 137, 378-387. [CrossRef]

6. Tiunov, A.V.; Scheu, S. Microbial Respiration, Biomass, Biovolume and Nutrient Status in Burrow Walls of Lumbricus terrestris L. (Lumbricidae). Soil Biol. Biochem. 1999, 31, 2039-2048. [CrossRef]

7. Pankhurst, C.; Pierret, A.; Hawke, B.; Kirby, J. Microbiological and Chemical Properties of Soil Associated with Macropores at Different Depths in a Red-Duplex Soil in NSW Australia. Plant Soil 2002, 238, 11-20. [CrossRef]

8. Athmann, M.; Kautz, T.; Banfield, C.; Bauke, S.; Hoang, D.T.T.; Lüsebrink, M.; Pausch, J.; Amelung, W.; Kuzyakov, Y.; Köpke, U. Six Months of L. Terrestris L. Activity in Root-Formed Biopores Increases Nutrient Availability, Microbial Biomass and Enzyme Activity. Appl. Soil Ecol. 2017, 120, 135-142. [CrossRef] 
9. Lavelle, P. Earthworm Activities and the Soil System. Biol. Fertil. Soils 1988, 6, 237-251. [CrossRef]

10. Jégou, D.; Cluzeau, D.; Hallaire, V.; Balesdent, J.; Tréhen, P. Burrowing Activity of the Earthworms Lumbricus terrestris and Aporrectodea Giardi and Consequences on C Transfers in Soil. Eur. J. Soil Biol. 2000, 36, 27-34. [CrossRef]

11. Don, A.; Steinberg, B.; Schöning, I.; Pritsch, K.; Joschko, M.; Gleixner, G.; Schulze, E.-D. Organic Carbon Sequestration in Earthworm Burrows. Soil Biol. Biochem. 2008, 40, 1803-1812. [CrossRef]

12. Andriuzzi, W.S.; Bolger, T.; Schmidt, O. The Drilosphere Concept: Fine-Scale Incorporation of Surface Residue-Derived N and C around Natural Lumbricus terrestris Burrows. Soil Biol. Biochem. 2013, 64, 136-138. [CrossRef]

13. Uteau, D.; Pagenkemper, S.K.; Peth, S.; Horn, R. Root and Time Dependent Soil Structure Formation and Its Influence on Gas Transport in the Subsoil. Soil Tillage Res. 2013, 132, 69-76. [CrossRef]

14. Ehlers, W.; Köpke, U.; Hesse, F.; Böhm, W. Penetration Resistance and Root Growth of Oats in Tilled and Untilled Loess Soil. Soil Tillage Res. 1983, 3, 261-275. [CrossRef]

15. Gaiser, T.; Perkons, U.; Küpper, P.M.; Puschmann, D.U.; Peth, S.; Kautz, T.; Pfeifer, J.; Ewert, F.; Horn, R.; Köpke, U. Evidence of Improved Water Uptake from Subsoil by Spring Wheat Following Lucerne in a Temperate Humid Climate. Field Crop. Res. 2012, 126, 56-62. [CrossRef]

16. Perkons, U. Bioporengenese durch homo-und allorhize Kulturpflanzen: Einfluss auf das Wurzelwachstum der Nachfrüchte. Dissertation. Ph.D. Thesis, University of Bonn, Bonn, Germany, 2018.

17. Fleige, H.; Grimme, H.; Renger, M.; Strebel, O. Zur Erfassung der Nährstoffanlieferung durch Diffusion im Effektiven Wurzelraum. Mitt. Dtsch. Bodenkd. Ges. 1983, 38, 381-386.

18. Kuhlmann, H.; Baumgärtel, G. Potential Importance of the Subsoil for the P and Mg Nutrition of Wheat. Plant Soil 1991, 137, 259-266. [CrossRef]

19. Pires, L.F.; Auler, A.C.; Roque, W.L.; Mooney, S.J. X-ray Microtomography Analysis of Soil Pore Structure Dynamics under Wetting and Drying Cycles. Geoderma 2020, 362, 114103. [CrossRef]

20. Stirzaker, R.J.; Passioura, J.B.; Wilms, Y. Soil Structure and Plant Growth: Impact of Bulk Density and Biopores. Plant Soil 1996, 185, 151-162. [CrossRef]

21. Pierret, A.; Moran, C.J.; Doussan, C. Conventional Detection Methodology Is Limiting Our Ability to Understand the Roles and Functions of Fine Roots. New Phytol. 2005, 166, 967-980. [CrossRef] [PubMed]

22. Bodner, G.; Leitner, D.; Kaul, H.-P. Coarse and Fine Root Plants Affect Pore Size Distributions Differently. Plant Soil 2014, 380, 133-151. [CrossRef] [PubMed]

23. Mitchell, A.; Ellsworth, T.; Meek, B.D. Effect of Root Systems on Preferential Flow in Swelling Soil. Commun. Soil Sci. Plant Anal. 1995, 26, 2655-2666. [CrossRef]

24. Han, E.; Kautz, T.; Perkons, U.; Lüsebrink, M.; Pude, R.; Köpke, U. Quantification of Soil Biopore Density after Perennial Fodder Cropping. Plant Soil 2015, 394, 73-85. [CrossRef]

25. Perkons, U.; Kautz, T.; Uteau, D.; Peth, S.; Geier, V.; Thomas, K.; Holz, K.L.; Athmann, M.; Pude, R.; Köpke, U. Root-Length Densities of Various Annual Crops Following Crops with Contrasting Root Systems. Soil Tillage Res. 2014, 137, 50-57. [CrossRef]

26. Han, E.; Kautz, T.; Köpke, U. Precrop Root System Determines Root Diameter of Subsequent Crop. Biol. Fertil. Soils 2015, 52, 113-118. [CrossRef]

27. Athmann, M.; Kautz, T.; Pude, R.; Köpke, U. Root Growth in Biopores-Evaluation with in Situ Endoscopy. Plant Soil 2013, 371, 179-190. [CrossRef]

28. Petzoldt, L.; Athmann, M.; Buechse, A.; Kautz, T. Root Growth of Hordeum Vulgare and Vicia Faba in the Biopore Sheath. Agriculture 2020, 10, 650. [CrossRef]

29. Jégou, D.; Schrader, S.; Diestel, H.; Cluzeau, D. Morphological, Physical and Biochemical Characteristics of Burrow Walls Formed by Earthworms. Appl. Soil Ecol. 2001, 17, 165-174. [CrossRef]

30. Pagenkemper, S.K.; Athmann, M.; Uteau, D.; Kautz, T.; Peth, S.; Horn, R. The Effect of Earthworm Activity on Soil BioporosityInvestigated with X-ray Computed Tomography and Endoscopy. Soil Tillage Res. 2015, 146, 79-88. [CrossRef]

31. Kolb, E.; Legué, V.; Bogeat-Triboulot, M.-B. Physical Root-Soil Interactions. Phys. Biol. 2017, 14, 065004. [CrossRef]

32. Parkin, T.B.; Berry, E.C. Microbial Nitrogen Transformations in Earthworm Burrows. Soil Biol. Biochem. 1999, 31, $1765-1771$. [CrossRef]

33. Agapit, C.; Gigon, A.; Puga-Freitas, R.; Zeller, B.; Blouin, M. Plant-Earthworm Interactions: Influence of Age and Proportion of Casts in the Soil on Plant Growth, Morphology and Nitrogen Uptake. Plant Soil 2017, 424, 49-61. [CrossRef]

34. Athmann, M.; Sondermann, J.; Kautz, T.; Köpke, U. Comparing Macropore Exploration by Faba Bean, Wheat, Barley and Oilseed Rape Roots Using in Situ Endoscopy. J. soil Sci. Plant Nutr. 2019, 19, 689-700. [CrossRef]

35. Pierret, A.; Moran, C.; Pankhurst, C. Differentiation of Soil Properties Related to the Spatial Association of Wheat Roots and Soil Macropores. Plant Soil 1999, 211, 51-58. [CrossRef]

36. White, R.; Kirkegaard, J.A. The Distribution and Abundance of Wheat Roots in a Dense, Structured Subsoil — Implications for Water Uptake. Plant. Cell Environ. 2010, 33, 133-148. [CrossRef]

37. Arvidsson, J.; Håkansson, I. Response of Different Crops to Soil Compaction—Short-Term Effects in Swedish Field Experiments. Soil Tillage Res. 2014, 138, 56-63. [CrossRef]

38. Lipiec, J.; Simota, C. Role of Soil and Climate Factors in Influencing Crop Responses to Soil Compaction in Central and Eastern Europe. In Developments in Agricultural Engineering; Elsevier BV: Amsterdam, The Netherlands, 1994; Volume 11, pp. 365-390. 
39. Li, H.B.; Ma, Q.H.; Li, H.G.; Zhan, F.S.; Rengel, Z.; Shen, J.B. Root Morphological Responses to Localized Nutrient Supply Differ among Crop Species with Contrasting Root Traits. Plant Soil 2014, 376, 151-163. [CrossRef]

40. Pätzold, S.; Vetterlein, D.; Jahn, R. DFG Research Unit 1320 Crop Sequence and the Nutrient Acquisition from the Subsoil. Description of the Reference Soil Profile. Available online: https:/ / www.cka.uni-bonn.de/standort/bodenprofilbeschreibung-cka (accessed on 28 November 2020).

41. Meier, U.; Bleiholder, B.; Buhr, L.; Feller, C.; Hack, H.; Heß, M.; Lancashire, P.D.; Schnock, U.; Stauß, R.; van den Boom, T.; et al. The BBCH System to Coding the Phenological Growth Stages of Plants-History and Publications. J. Kult. 2009, 61, 41-52.

42. Littell, R.C.; Milliken, G.A.; Stroup, W.W.; Wolfinger, R.D.; Schabenberger, O. SAS for Mixed Model, 2nd ed.; SAS Institute Inc.: Cary, NC, USA, 2006.

43. Patterson, H.D.; Thompson, R. Recovery of Inter-Block Information when Block Sizes are Unequal. Biometrika 1971, 58, 545-554. [CrossRef]

44. Piepho, H. A SAS Macro for Generating Letter Displays of Pairwise Mean Comparisons. Commun. Biometry Crop Sci. 2012, 1, 4-13.

45. Hsu, J.C. The Factor Analytic Approach to Simultaneous Inference in the General Linear Model. J. Comput. Graph. Stat. 1992, 1, 151. [CrossRef]

46. Materechera, S.A.; Dexter, A.R.; Alston, A.M. Penetration of Very Strong Soils by Seedling Roots of Different Plant Species. Plant Soil 1991, 135, 31-41. [CrossRef]

47. Materechera, S.A.; Alston, A.M.; Kirby, J.M.; Dexter, A.R. Influence of Root Diameter on the Penetration of Seminal Roots into a Compacted Subsoil. Plant Soil 1992, 144, 297-303. [CrossRef]

48. Zobel, R.W.; Kinraide, T.B.; Baligar, V.C. Fine Root Diameters Can Change in Response to Changes in Nutrient Concentrations. Plant Soil 2007, 297, 243-254. [CrossRef]

49. McCormack, M.L.; Dickie, I.A.; Eissenstat, D.M.; Fahey, T.J.; Fernandez, C.W.; Guo, D.; Helmisaari, H.; Hobbie, E.A.; Iversen, C.M.; Jackson, R.B.; et al. Redefining Fine Roots Improves Understanding of Below-Ground Contributions to Terrestrial Biosphere Processes. New Phytol. 2015, 207, 505-518. [CrossRef]

50. Bengough, A.G. Root Elongation Is Restricted by Axial but Not by Radial Pressures: So What Happens in Field Soil? Plant Soil 2012, 360, 15-18. [CrossRef]

51. Lucas, M.; Schlüter, S.; Vogel, H.-J.; Vetterlein, D. Soil Structure Formation along an Agricultural Chronosequence. Geoderma 2019, 350, 61-72. [CrossRef] 